\title{
ROLE OF CONSUMER PSYCHOLOGICAL STUDIES IN FAST FOOD INDUSTRY
}

\author{
Adnan Arshad \\ National College of Business Administration \& Economics, Pakistan \\ E-mail: adnanarshad993@gmail.com \\ Shahzaman Khan \\ National College of Business Administration \& Economics, Pakistan \\ E-mail: Shahzman_khan@ @otmail.com \\ Usman Zafar \\ Institute of Business Management, Pakistan \\ E-mail: usman.zafar93@outlook.com \\ Ayesha Abdul Qadir \\ Superior University Lahore, Pakistan \\ E-mail: ayeshaaqadir25@gmail.com
}

\begin{abstract}
This study examines the behavior of consumer in fast food industry. The customer psychology strongly effected from other customer's word of mouth, review's and pricing policy of a company. In this study, we examine the consumer psychology with three factors (referent price, referent deservingness and fair pricing). The three factors become a cause to reduce the anger of consumer and due to this customer satisfy from the operations of fast food industry. We distribute more than 300 questionnaire for analyze our research hypothesis. After analyze we conclude that referent price does not impact on customer anger but it impact on satisfaction of customer. The referent deservingness and price fairness has significant impact on anger of customer and satisfaction of customer. This study provides useful information to fast food sector regarding customer psychology.
\end{abstract}

Keywords: Price Fairness, Customer Psychology, Referent Price, Deservingness, Satisfaction.

\section{INTRODUCTION}

Fast food is a highly growing industry in the present era (Trafialek et al., 2019). Fast Food that food who needs very little time for preparation and serving a customer; most of the people like it very much, as compared to traditional food due to its price and its delicious taste (Xiao, Yang, \& Iqbal, 2018). It's suggested, that in $205060 \%$ more food will be produced for the 9 billion people in the world (FAO, 2019). In Pakistan it's the second-largest industry and ranks 8th worldwide, it contributes $16 \%$ in total employment. More than 1000 large food processing corporations operate here. Even every person spends approximately $42 \%$ of its income on food and retail sales $10 \%$ expand annually. The fast food business is growing $20 \%$ annually. 
Consumers spend very little time to understand the fast food recipes and to purchase it (Souiden, Chaouali, \& Baccouche, 2019). The behavior of Consumers concerning food steadily developed day by day (Savelli et al, 2019). Now, they don't like to spend more time to preparing food in their home, like a traditional way, but they like to eat those foods that are being prepared by others with short time and cost (Rai \& Rawal, 2019). Thereby, the fast-food industry is growing.

Savelli et al. (2019) conclude that, today youngster more like fast food, because it takes little time to prepare and it can be served to customer within a limited efforts (Pérez Villarreal, 2020) just like pasta, bread, fruits, etc. They found positive result after a thorough study on the behavior of Italian students concerning quality and buying decision of fast food. That's why, the fast-food industry is becoming a trend in present era due to its fair price and quality (Ahmed, Naseer, Asadullah, \& Khan, 2020) hereby customers initially observe the price and quality of fast food, if it is fair, then they make their behavior regarding the purchase it (Trafialek et al. 2019) otherwise, they turn back toward traditional food. The customer's experience and review's regarding company operations are very important source for new customer during purchase decision and company's also to form pricing and servicing policies (Van, 2016; Watkinson, 2013). On the other hand, fast food is spreading health diseases in customers just like diabetes, fats, etc (Xiao, Yang, \& Iqbal, 2018; Ibitomi, 2018). Customer firstly observes, whether the price of products justify its outcome being desired by them or not (Susilo, 2020). Equity theory suggests that multiple price offering concerning to specification products and service is a key factor to satisfy the customers for further business (Lastner et al., 2019; Kim, 2018). Referent and fair price offering has a strong appeal in the fast-food industry (Jothilakshmi, 2019). So, there have a need to understand the factors that impact customers' behavior to accept the price for products \& services for satisfaction through pricing policy of company.

The objectives of this study are as follows:

- To examine the relation of referent price and customer anger.

- To examine the relation of referent price and satisfaction.

- To examine the relation of referent deservingness and satisfaction.

- To examine the relation of price fairness and customer anger.

- To examine the relation of price fairness and satisfaction.

- To examine the relation of customer anger and satisfaction.

- To check the mediation of customer anger between referent price and satisfaction.

- To check the mediation of customer anger between referent deservingness and satisfaction.

- To check the mediation of customer anger between price fairness and satisfaction.

For achieve the satisfaction of customers is essential for the fast food industry to charge fair price from customers on every product \& service (Riquelme et al., 2019; Trafialek et al., 2019)) means that all prices of product satisfy the customer expectations and being effected from referent price, referent deservingness, price fairness and customers anger being crossed by it (Lastner et al., 2019). The companies should form those pricing policies who being followed by their relevant businesses, because if customers get negative word of mouth through referent customer and they realize that the product's prices is not fair, then they become angry and they avoid to transact anymore ( Riquelme et al., 2019; Tuzovic et al., 2014; Susilo, 2020). The anger is also an important element in order to get satisfaction of customer that arises from social, cultural gap, it's very important for companies to realize the negative factors, because without 
eliminating these factors fast food industry could not satisfy the customer (Adam \& Brett, 2018). Fair price means, that customer realizes, that fast food charge the reasonable price for a products, while numerous offering available in the market, otherwise they will be turned to another product (Hasim, Manaf, \& Ali, 2020; Zietsman, Mostert, \& Svensson, 2019). Equity theory states, that motivation of any person toward the specific action arises, when he/she realize, that these actions are going to his/her financial favor. The quality of product $\&$ service could also judge by its price and reference of customer is the prime factor that remains satisfy the customer (Ahrholdt, Gudergan, \& Ringle, 2019).

Satisfaction is a positive mental state of customers that will be developed after consuming the product or services (Yusheng \& Ibrahim, 2019; Khokhar \& Khokhar, 2020). Ogbechi, Okafor and Orukotan (2018) states that there are multiple features in products \& services that plays a vital role to create satisfaction in customers. So, companies need to follow the customer psychological studies and showing Excellency in their performance (Suhud et al., 2020). Price is the most important feature among them, who directly affects customers' behavior. Price represents the outer quality of products and retains customers for a long time with specific product or service, especially in fast food (Hikmawati et al., 2018). Ibitomi (2018) concludes that fast food industry most growing industry during these days and fair pricing, referent pricing and deservingness has core reason for it. If customers realize that the price is fair of this products and other customer also accept this product on this price, then they transact business, otherwise they move from here. Lastner et al. (2019) concludes that whenever customers realize negative feeling regarding pricing policies of fast food. Then, he/she shows anger towards products. Furthermore, if other customers' also provide negative references regarding fair price, then these negative feeling more grow and if the reference is positive, then anger tend to diminish. The anger in customers arises from multiple sources, but in social emotions, it mainly arises from other customer's references and their own experience (Le \& Ho, 2020). It also provides a great experience to companies for learn the customer psychology (Van, 2016). Customer satisfaction in fast food industry comes after eliminating negative feeling through price fairness, referent pricing and referent deservingness. When customers realize, that price of fast food product is fair, then they transact with the company (Ali, Imm, Yee, \& Akhtar, 2018). Equity theory also states, that fair price has a vital role to motivate anyone toward specific action or transaction, especially in food industry, it cores element to create satisfaction in customers through pricing and deservingness companies can diminish anger of customer and finally the customer satisfy (Weber, Bradley, \& Sparks, 2017; Lastner et al., 2019).

\section{Referent price and Satisfaction}

\section{LITERATURE REVIEW}

Today every company charge variant price for a customer against their product quality, features, cost etc (Atmaja \& Yasa, 2020). The purpose of this practice is to enhance the satisfaction of customer. The fast food industry deals with every class of a customer. Hereby, every customer has their own choice, taste, preferences and purchasing power (Konuk, 2019). In which the most prominent factor who stimuli the satisfaction of customer is pricing policy of a company. Every customer initially checks product quality, features with a price. Especially, the word of mouth and reaction of other customers against the product price (Atmaja \& Yasa, 2020). For this purpose, companies should make their pricing policies in the light of customer's behavior for enhance their satisfaction (Goussinsky, 2015). In equity theory states, that only satisfied 
customers could feel that company treat fair with them and they do not only motivate for further transaction, but also refer other customers there ( Lastner et al, 2019).

\section{$H_{1}$ There is significant relationship between referent price and customer satisfaction Referent price and Customer Anger}

The anger is the emotional feedback of customers toward the services of companies and gives the opportunity to companies to moderate their services accordingly (Min, Joireman, \& Kim, 2019). For this purpose, restaurant should amend their pricing policies for getting the satisfaction of customers (Cheshin et al., 2018). The companies should form strategy for monitoring, amending and improving the customers' feedback process and try to eliminate negative factors that impact on customers' behavior, because due to excessive use of ecommerce customers' feedback/ review are becoming very popular for assess the company's performance (Ismagilova, Dwivedi, \& Slade, 2019; Chowdhury, 2021). Customer's anger could be eliminated by charge fair price for a product; that is generally accepted and referred by all customers (Glikson et al., 2019; Jerger \& Wirtz, 2017). So, the company should monitor the feedback and reviews of customer regarding price, in order to create positive image in a market. Thereby, every customer become a pillar of positive environment of company in a market hereby, a company can also control those factors who become a cause of customer anger (Goussinsky, 2015). In equity theory states that if anyone realizes that the company treats unfair with it financially, and then he/she will have been becoming angry and will not be willing to execute the further transaction (Lastner et al., 2019) in this situation, referent price can handle this situation and bring turn back to it.

\section{$\mathrm{H}_{2}$ There is significant relationship between referent price and customer anger Referent deservingness and Customer Anger}

Rai and Rawal (2019) concludes that fast food useful for time-saving, money saving. Furthermore, other consumers are also refer it to another customer, because they consider that the fast deserve for them. That's why, fast food becomes most familiar everywhere especially, in the busy life of cities. Life has become very busy, now a day nobody has much time to search and select food in the presence of number of choices in the market. In this situation references of other customers are very important; in this way one can get a food that have a fair price and favorable taste with little effort (Kokkoris, Sedikides, \& Kühnen, 2019). Customer anger regarding product can be eliminate if other customer refer this product to other customer. Those customers who have similar characteristics and perception regarding product quality and price, they can refer the product to each other. In this way, if any customer has a negative feeling regarding product, then other customer reference can be moderate the behavior and negative feeling change into positive feeling (Konuk, 2019). Because in equity theory states that if anybody feels that company's not fairly treating it in a financial manner, then he/she will be turn from there. In this situation, other customer's group reference is very important, because in this way one can realize that he/she treated by the company with justice and fairly (Lastner, 2019; Feather, 2015). 


\section{$\mathrm{H}_{3}$ There is significant relationship between referent deservingness and customer anger Price fairness and Customer Anger}

Today fast food is becoming a sign of high social status. People mostly eat food outside from home to show their sound financial worth (Atmaja \& Yasa, 2020). Furthermore, there is an increase in customer spending on food as compare to previous years. Thereby, there is also an increase in number of restaurants in fast food market (Hasim, Manaf, \& Ali, 2020). That's why, there is need to deeply examine the consumer behavior to increase market share. In which, the most important element is price fairness (Hasim, Manaf, \& Ali, 2020). If the price level is most low then it became bad factor for restaurant, hereby if price level keep at high then it became bad factor for customer. If price does not match with customer perception and their financial worth, then they become angry and move from here (Konuk, 2019).

\section{$\mathrm{H}_{4}$ There is significant relationship between price fairness and customer anger Price fairness and Satisfaction}

While customers are involving in buying decision then Price does an important role to select favorable products then it meets customer's expectation and satisfies those (Qalati et al., 2019; Ahmed, Naseer, Asadullah, \& Khan, 2020). In fast food the industry has high appeal to form price in the light of customers expectation for getting satisfaction because customers are steadily turning from traditional food towards fast food in this situation, if the price does not meet customers expectation, then customers will turn back (Souiden, Chaouali, \& Baccouche, 2019). Darmawan (2018) concludes that price has primary importance in customers purchase decision when customer involves in buying decision making, then he/she firstly mostly pay attention towards price if the price meets with his/her expectation then customers pay attention towards other features otherwise vice versa. Everyone wants to get satisfaction through products, because satisfaction is the mental state of customers, in which products qualify to meets customers expectation(Ismagilova, Dewivedi, \& Slade, 2019) for this the purpose, there are numerous factors who impact on customers purchase decision to get satisfaction, but among these factors, price is very important (Shah, Husnain, \& Zubairshah, 2018). So, fast food industries firstly focus on their pricing policy to attract and satisfy customers.

\section{$\mathrm{H}_{5}$ There is significant relationship between price fairness and customer satisfaction Customer anger and Satisfaction}

Anger is the negative feeling arises in customers mind concerning product \& service, when they feel unfair treatment from the company (Le \& Ho, 2020; Riquelme et al., 2019). These negative feeling mainly arises after using a product and most important other customers reviews or feedback, especially in the fast food industry (Izquierdo-Yusta et al., 2019). The negative emotions in customer's mind arise from many sources and they become a source of learning opportunity to companies (Van, 2016). If companies' services for customers do not match with their perception, then customer becomes angry and dissatisfy there (Iyiola \& Ibidunni, 2013). So, this anger of customer leads toward dis-satisfaction and only well trained marketing employee can handle this situation and turn back the customer on company's platform for further business (Glikson et al., 2019; Cheshin et al., 2018; Jerger \& Wirtz, 2017). Today the number of restaurants is increasing rapidly and they involve in fierce competition (Pérez 
Villarreal, 2020) and every customer put his/her own positive or negative feedback on online customers' review system, in this situation's very necessary to provide customers excellent service better than competitors and eliminate negative factors from services, just like over pricing, lead time and negative word of mouth (Min, Joireman, \& Kim, 2019) in order to creating positive emotions in customers for achieving the satisfaction of customer (Dinçer \& Alrawadieh, 2017; Cai \& Chi, 2018). In fast-food industry have fierce competition there are numerous factors have prevailed in restaurants, who are becoming helpful in exploring and attracting customers' among these factors price is the core factor who have a primary influence on customers' if price achieve customers expectation, then customer examine the features of the product and when this products performance overcome the negative feeling of customers, then the fast-food industry achieve satisfaction (Ferguson, 2014). In equity theory states, that if customers feel that the money who they are going to pay for products fulfill their expectations, then they satisfy from restaurant and motivate to transact with it in the future (Lastner et al., 2019).

\section{$H_{6}$ There is significant relationship between customer anger and customer satisfaction Referent price, Customer anger and Customer Satisfaction}

Dekker (2018) concludes, that some restaurants in Europe allow customers to eat meals and enjoy their services after finish it, they gives a right to customers, which they own to decide what should be paid for them. Price should be set on that level, where customers deserve it, in this situation, other customers review's also very important (Ahmed, Naseer, Asadullah, \& Khan, 2020). For this purpose, the company charges low prices with new customers in order to retain it and also check the purchase history of existing customers to change their pricing strategy accordingly, to get higher satisfaction of customers (Lee \& Fay, 2017). Watkinson (2019) concludes, that if specific brand or service fulfill the customers' expectation just like price, taste, etc. and overcome the negative feelings in customers' towards it, then customer' demand for this product in the future repeatedly. If companies services are not met with the expectation of customers, then customers not satisfy there (Iyiola \& Ibidunni, 2013). So, it's very necessary to collect and analyze customers feedback carefully and write down the major negative factors in services, then form policies to uproot these factors (Trafialek et al., 2019) it's not possible to eliminate fully negative factors from services, but it must be goes down if restaurants seriously struggle to overcome it (Noeth, 2018). Other customers' review does an important role for new customers, when they involve in checking the price of products and, then realizing that this product deserves for this price or not in this situation restaurants should carefully analyze the customer's feedback review for retain existing and attracting new customers (Renic \& Mandic, 2018). In equity theory states, that if all customers realize that restaurant charges fair prices with all of us, then they realize that this restaurant is best for this product (Ashworth \& McShane, 2012; Lastner et al., 2019).

\section{$\mathrm{H}_{7}$ Customer anger mediates the relationship between referent price and customer satisfaction Customer Anger, Price fairness and customer satisfaction}

In a fast food industry has fierce competition now a day. So, in order to get competitive edge every fast food company fully and enthusiastically focuses on their operations. In this situation, sometime they violate the customer perception and formulate pricing and quality policies regarding product on the basis of their own experience (Hasim, Manaf, \& Ali, 2020). 
Thereby, they receive complain from customer. These complain become a learning opportunity for fast food industry. Because complain provide clear guideline to industry for track their mistake. Mostly these complain belongs to pricing (Atmaja \& Yasa, 2020). If price is not fair then customer definitely filed a complaint in company regarding it. The unfair price becomes a customer's angry and he/she does not want to transact with a company (Konuk, 2019). So, anger mediates the relation between satisfaction and anger. If anger is high then this relation becomes weak and if anger is low then this relation strength goes to high (Le \& Ho, 2020). So, companies try to diminish the anger of customer in order to strength the relationship between price fairness and satisfaction of customer.

\section{$\mathrm{H}_{8}$ Customer anger mediates the relationship between price fairness and customer satisfaction Customer Anger, referent deservingness and customer satisfaction}

Deservingness is a positive feeling of someone towards the price of goods \& services arise from online feedback reviews of other customer's and the customer's own experience (Ismagilova, Dewivedi, \& Slade, 2019; Suhud et al., 2020). In the present era everyone involves in decision making between multiple offering and selection of those products that are beneficial for them especially, in a financial manner (Pérez Villarreal, 2020). In this situation, other customer's review plays a vital role for anyone to make mind or emotion concerning products, that those products deserve for this price or not (Kokkoris, Sedikides, \& kuhnen, 2018; Abeyta, Routledge, \& Sedikides, 2017). In fast-food industry have multiple offering for customers and only by referring or influencing of other customer's anyone can feel that products of this industry deserve for these prices or not, then they will be motivated toward this product. In equity theory states that, if anyone feels that company create it fairly in a financial manner, then it will become more motivated toward them (Lastner et al., 2019).

\section{Ho Customer anger mediates the relationship between referent deservingness and customer satisfaction}

\section{METHODOLOGY}

The target population for this research was customers of different fast food companies. A large number of customers participated in this research. We used a schedule questionnaire to analyze the proposed hypothesis. For measure, the customer's anger measure collected from (Bolton et al, 2010) and for referent deservingness measure collected from (Ashworth \& McShane, 2012) and for price fairness measure collected from (Malekwa, 2014) and for customer's satisfaction measure collected from (Raghunathan \& Irwin, 2001). The fast-food companies didn't maintain their customers' record properly and there are no authentic online portals of fast-food customers' data. So, we used a convenience sampling technique and collect data from 306 respondents. The researchers himself approached to their respondents and also give refreshment against their response. The respondents belonged to different local, national, and international fast-food brands. After collecting the data, we used SPSS to measure the descriptive analysis and frequencies of data. Furthermore, we used AMOS for structural equation modeling and test the validity and hypothesis of this study. 
Table 1. Sample items measurement

\begin{tabular}{|c|c|c|}
\hline & Items & Reference \\
\hline Customer Anger & $\begin{array}{l}\text { Thinking about the price } \\
\text { charged for this (product) } \\
\text { makes me frustrated }\end{array}$ & (Bolton et al. 2010) \\
\hline Referent deservingness & $\begin{array}{l}\text { The other customer deserved } \\
\text { to pay a lower price than me. }\end{array}$ & $\begin{array}{l}\text { (Ashworth \& McShane, } \\
\text { 2012) }\end{array}$ \\
\hline Price fairness & $\begin{array}{l}\text { The price I am paying is fair } \\
\text { for service }\end{array}$ & (Malekwa, 2014) \\
\hline Customer satisfaction & $\begin{array}{l}\text { This service provider fulfilled } \\
\text { my needs }\end{array}$ & $\begin{array}{l}\text { (Raghunathan \& Irwin, } \\
\text { 2001) }\end{array}$ \\
\hline Referent price & $\begin{array}{l}\text { The other customer and I paid } \\
\text { the exact same amount for the } \\
\text { food. }\end{array}$ & (Lastner et al, 2019) \\
\hline
\end{tabular}

CONCEPTUAL MODEL

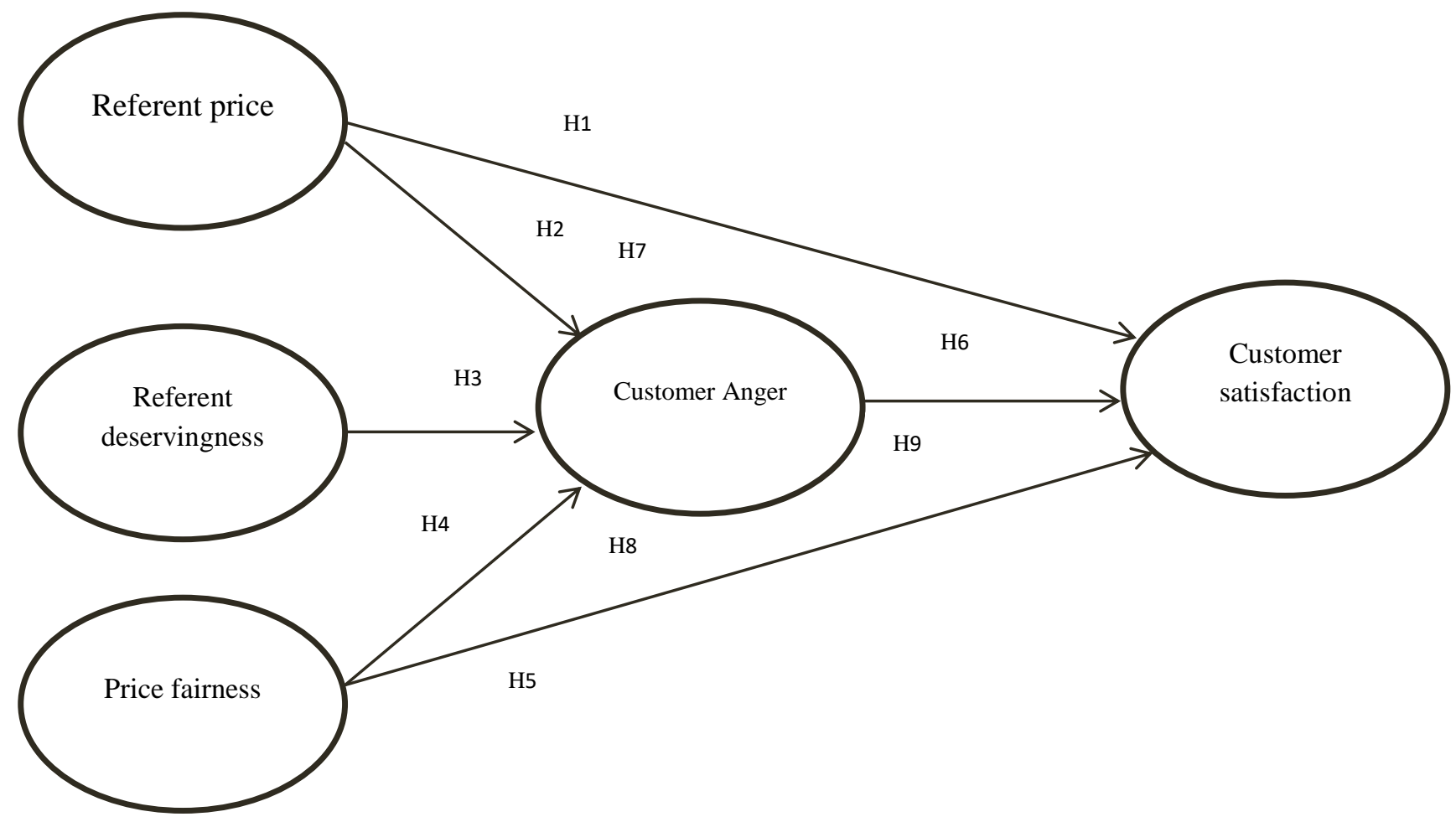

Figure 1. Conceptual framework

\section{ANALYSIS AND DISCUSSION}

In first we check the reliability of data. In order to check the reliability, we use Cronbach alpha value (Cronbach, 1951) for all proposed variables. In this test I check the internal consistency of data who always fall between 0 to 1 referred by (Tavakol \& Dennick, 2011) in the below table I show the Alpha value of each variable and overall. All values have an alpha value above .78 and 
near to .9 who is very fruitful for our research. After this test, I come to know that our research data is best for our further analysis.

Table 2. Alpha value of each variable and overall

\begin{tabular}{|l|l|l|l|}
\hline Variables & No. of Items & Alpha & KMO \& BARTLET \\
\hline Customer Anger & 4 & .825 & .676 \\
\hline Referent deservingness & 4 & .828 & .802 \\
\hline Price fairness & 8 & .889 & .891 \\
\hline Customer Satisfaction & 4 & .782 & .764 \\
\hline Referent Price & 4 & .919 & .738 \\
\hline Overall & 24 & .902 & .738 \\
\hline
\end{tabular}

We also, check the adequacy of data for this purpose; we do a test of Kaiser Meyer Olkin (KMO) and Bartlet. The purpose of this test is to check that the data is sample error-free or not. The disrupt data eradicated from our research or not. For this purpose, Kaiser suggests value is .5 if values of this test near to .5 and above from it and near to .9 then our data is useful for our research (Kaiser, 1974; Cerny \& Kaiser, 1977). In the above table, our variables value above 6 and the highest value is .891 of price fairness it means our data is free from sampling error and all data is valuable for our research.

In this research 306 respondents participate, who belongs to different fast-food restaurants and brands and there are no missing values in this research data. The males are more participate as compare to female, hereby the mean of gender is 1.3366 and the standard deviation is .47332. The variation of means is very minor in this test and rang is 1 . They have positive skewness means data is upward from means .695. The average age of respondent is 22.4118 means mostly respondent is teenage. We already know that mostly youngsters like the fast food (Khokhar \& Khokhar, 2020). The standard deviation of age is 4.41240 , means only 4.4 years difference from mean and the range is 35 years it means our respondents mostly youngster and teenage. The skewness of age is 1.537 means the skewness is positive and the value is more than mean. The years of affiliation participants with their respective brands are more than 5 years and 3.63351 standard deviation means variation from mean of data is 3.6, it is low risk and the range is 24 years. It has positive skewness is .457 means it above the mean. In variables, customer anger and referent deservingness mean is 2.6 and 2.9 respectively, it means mostly respondents disagree with our questions here, but the standard deviation is .8632 and .9376 means variation is very high from the mean. So, we can't say that the respondent totally disagrees with our questions. The range of this test is 4 and skewness is positive in .457 for customer anger and negative -.103 for referent deservingness. It means in customer anger response is above from mean and in deservingness response is below than mean. The price fairness and customer satisfaction mean is 3.1846 and 3.1528 respectively means respondent mostly respondent agree with our questions but the standard deviation is .84774 and .88853 respectively and range is 4 . So, we can't say all respondents agree with our questions, because risk is very high. The skewness is -.521 and -.155 means both skewness below than mean.

The next, we test the correlation between variables. For this purpose, we form the measurement model of all variables on Amos and fit the model for further analysis and we found correlation and covariances of variables. The correlation means the relations of variables strong or weak this relation test through a beta estimate of all variables. In below table shows the 
relationship between variables and their estimates. The correlation relationship falls between -1 and +1 . The -1 mean there is a negative relationship between a variable and +1 show the strong positive relationships exist between variables and 0 means there is no relationship between variables (Galton \& British, 1885; Pearson, 1895). In this table, we can see all relationship is positive and strongly correlated between them. In which, the most positive relation is referent deservingness and customer Anger who is .773. It is the strongest relation and referent price and price fairness have low positive relation who is .401 .

Table 3. Correlation between variables

\begin{tabular}{|l|l|l|}
\hline VARIABLES & VARIABLES & ESTIMATES \\
\hline Referent Price & Referent deservingness & .430 \\
\hline Referent Price & Price fairness & .401 \\
\hline Referent Price & Customer Anger & .554 \\
\hline Referent Price & Customer satisfaction & .508 \\
\hline Referent deservingness & Customer Anger & .773 \\
\hline Price fairness & Customer Anger & .636 \\
\hline Referent deservingness & Customer satisfaction & .636 \\
\hline Price fairness & Customer satisfaction & .636 \\
\hline
\end{tabular}

The below diagram shows the covariance's between variables. The estimate means the beta value between variables. It shows the strength of the relationship between variables. In this diagram strongest relationship falls between referent deservingness and customer anger who is .747. The standard error shows the other variables effect on relationships and all relation is significant. It means the relation of the variables is strongly supported by our research.

Table 4. Strength of the relationship between variables

\begin{tabular}{|l|l|c|c|c|}
\hline VARIABLES & VARIABLES & Estimate & Standard error & P- Value \\
\hline Referent Price & $\begin{array}{l}\text { Referent } \\
\text { deservingness }\end{array}$ & .345 & .066 & .000 \\
\hline Referent Price & Price fairness & .386 & .077 & .000 \\
\hline Referent Price & Customer Anger & .470 & .074 & .000 \\
\hline Referent Price & $\begin{array}{l}\text { Customer } \\
\text { satisfaction }\end{array}$ & .556 & .091 & .000 \\
\hline $\begin{array}{l}\text { Referent } \\
\text { deservingness }\end{array}$ & Customer Anger & .747 & .093 & .000 \\
\hline Price fairness & Customer Anger & .736 & .099 & .000 \\
\hline $\begin{array}{l}\text { Referent } \\
\text { deservingness }\end{array}$ & $\begin{array}{l}\text { Customer } \\
\text { satisfaction }\end{array}$ & .736 & .099 & .000 \\
\hline Price fairness & $\begin{array}{l}\text { Customer } \\
\text { satisfaction }\end{array}$ & .736 & .099 & .000 \\
\hline
\end{tabular}

The below table shows the standardized beta and unstandardized beta ad standard error. It is not possible that all variables have variances according to our estimation. Because our 
estimation shows through standard deviation, but some time variation in a variable doesn't follow the variation shows in standard deviation. So, for the measurement, this type of variation, we use the unstandardized coefficient in the below table, unstandardized beta is positive in all independent variable case and it is low in referent deservingness .068 and high in price fairness who is .523. The standard error shows the variation occurs due to other variables that we are not estimated (Arshad, Jugo \& Rohin, 2017). If variation in independent variable following the standard deviation, then we can say it is standardized variation and it is shown in beta given below that is low in referent deservingness is .071 and high in price fairness is .499 .

Table 5. Standardized beta and unstandardized beta ad standard error

\begin{tabular}{|c|c|c|c|c|c|}
\hline Variable & \multicolumn{2}{|c|}{ Unstandardized Coefficient } & Standardized & \multicolumn{2}{c|}{ Collinearity Statistics } \\
\hline & Beta & Standard error & Beta & Tolerance & VIF \\
\hline Referent Price & .100 & .054 & .097 & .766 & 1.306 \\
\hline $\begin{array}{c}\text { Referent } \\
\text { deservingness }\end{array}$ & .068 & .059 & .071 & .545 & 1.835 \\
\hline Price fairness & .523 & .069 & .499 & .484 & 2.065 \\
\hline
\end{tabular}

In the above table secondly, we test the collinearity of the independent variable. The purpose of this test is to analyze whether the independent variable highly correlated among them or not. Because, if all independent variables highly correlated among them, then it creates a low impact on the independent variable and our model will not be fit. In this test, we check two values one degree of tolerance and the second is VIF (variance inflation factor). To value of tolerance must be below +1 and in the above table all valued below +1 and VIF value must be below 10 and in this table value of all VIF below 10 (Yang \& Lee, 2008; Johnston, Jones \& Manley, 2018). So, we have no worry about the collinearity problem in our model. Our model is fit for further analysis.

\section{Measurement Model}

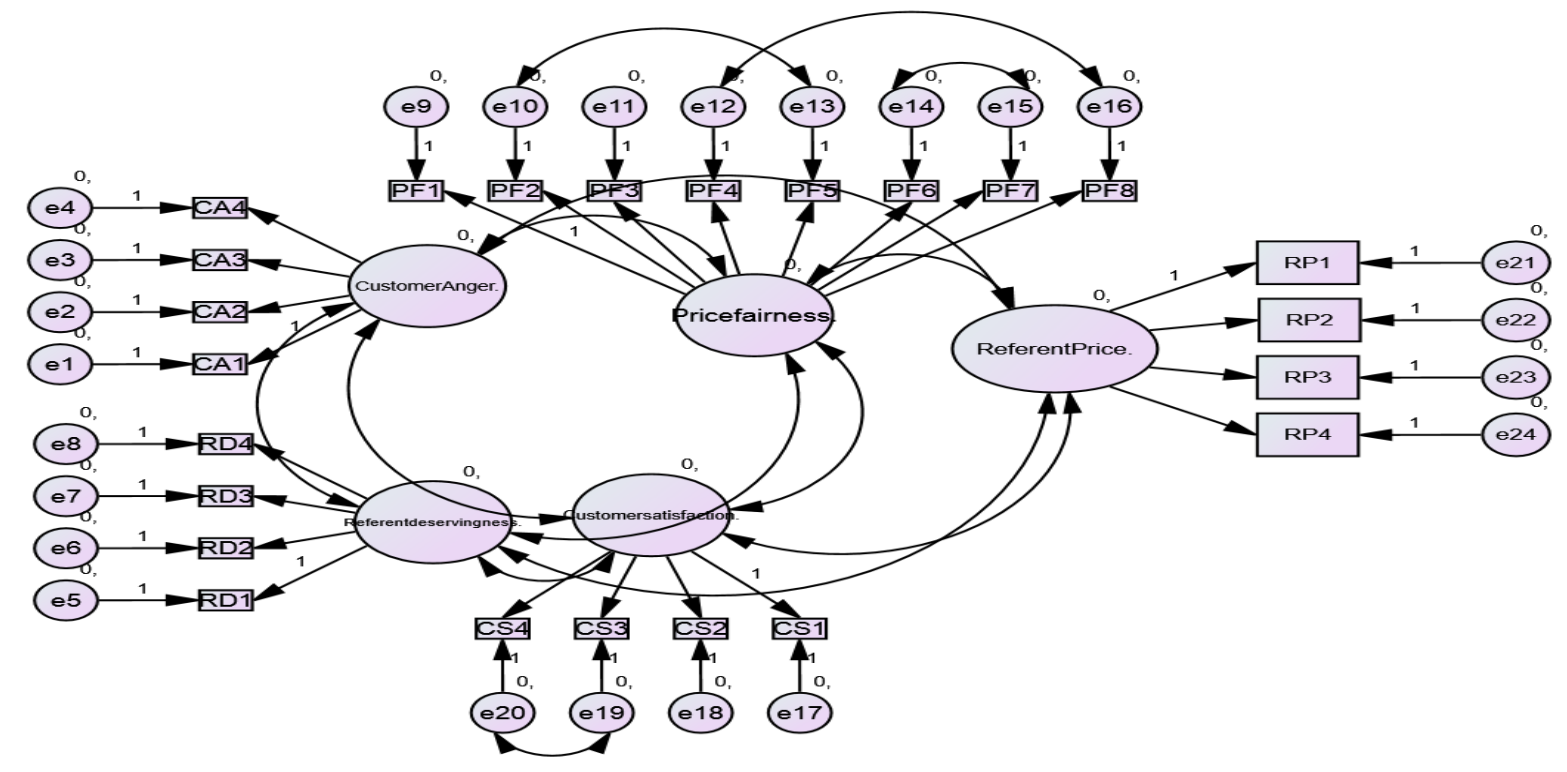

Figure 2. Measurement Model 
Table 6. Model Fit

\begin{tabular}{|l|l|}
\hline METRIC & OBSERVED VALUE \\
\hline Cmin/df & 3.194 \\
\hline CFI & .886 \\
\hline RMSEA & .085 \\
\hline PCLOSE & .000 \\
\hline GFI & .854 \\
\hline
\end{tabular}

In order to check the model is fit or not. We check the value of a few items in which, $\mathrm{cm}$ in difference, CFI (comparative fit index), GFI (Goodness of fit index), RMSEA (root mean square error of approximation) all the value compare with different threshold and concludes that our measurement model is fit for this study.

\section{Structural Equational Model}

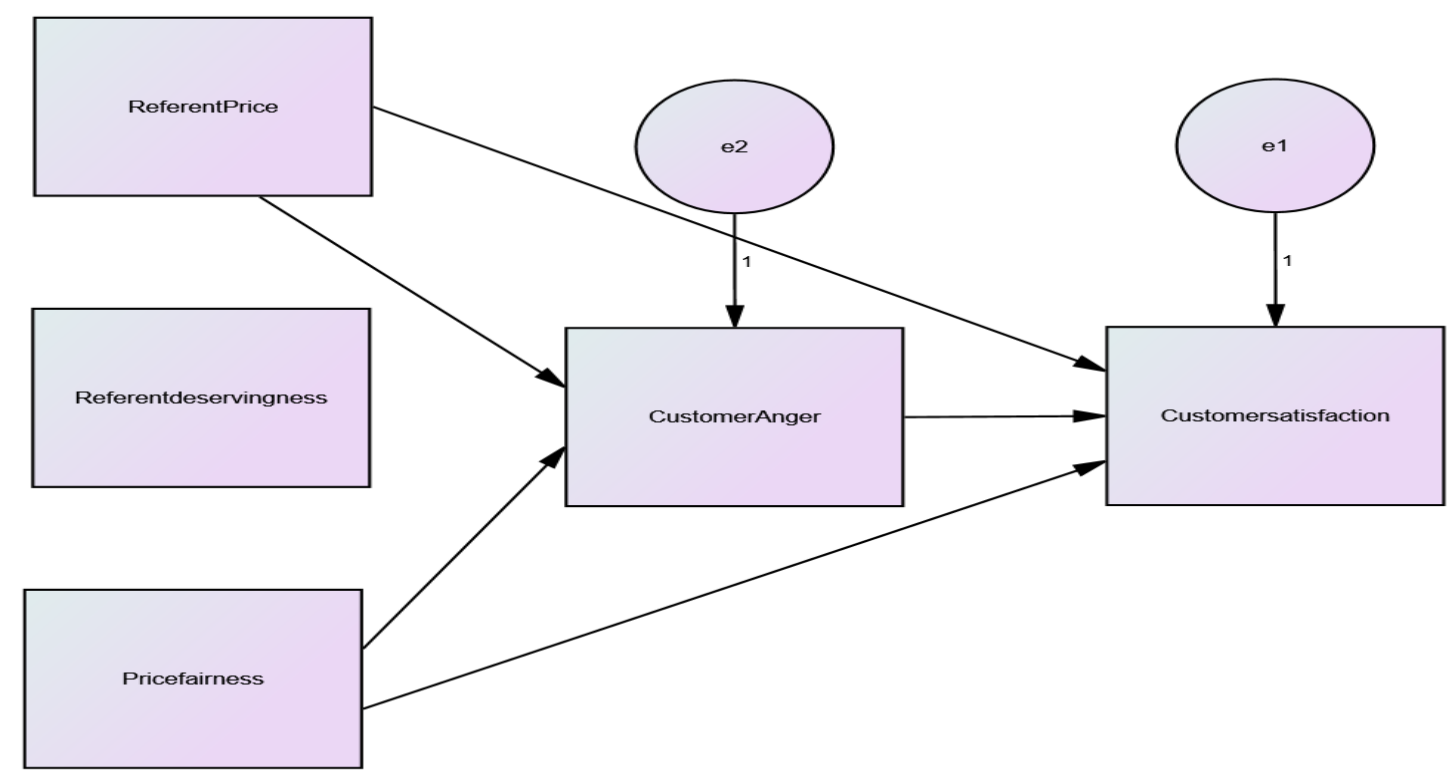

Figure 3. Structural Equational Model

Table 7. Model Fit

\begin{tabular}{|l|l|}
\hline METRIC & OBSERVED VALUE \\
\hline Cmin/df & 44.124 \\
\hline CFI & .891 \\
\hline RMSEA & .376 \\
\hline PCLOSE & .000 \\
\hline GFI & .937 \\
\hline
\end{tabular}

We also, do structural equation modeling to check the hypothesis. The values, who we already select in the measurement model, also check in this step and compare with different threshold especially (Hu $\&$ Bentler, 1999) and conclude that model is fit for our study. 


\section{Hypothesis Testing}

In order to test the hypothesis, we check the values calculated in structural equation modeling. Weather, the hypothesis supports our study or not. Our first hypothesis is "There is significant relationship between referent price and customer satisfaction" The strength of this relation is .100 who is very weak and standard error is .054 who is also very low. So, there is no more problem of weakness in strength and finally, when I see the P-value of this relation who I took it .05 . The P-value of this relation is .064 who is $.064>.05$. So, I conclude that there no significant relationship between referent price and satisfaction. It means the referent price does not important to get satisfaction. The second hypothesis is "There is significant relationship between referent price and customer anger". The strength of this relation is .265 , who is significant relation and standard error of this relation is .042 , which is also good it means other factor does not create a significant impact on this relation. The P-value of this relation is .000 who is $.000<.05$. So, I conclude that there is a significant relationship between referent price and customer anger. It means if companies better monitor the referent price and form its policies accordingly, then customer anger can be removed. The third hypothesis of this study is "There is significant relationship between referent deservingness and customer anger" The strength of this relation is .068 who is the weak and standard error of this relation is .059 who is also very weak and P-value of this relation is .005. It means .005>.05. So, I conclude that there is significant relation between referent deservingness and customer anger. It means companies should try their level best in monitoring referent deservingness to remove customer anger. The fourth hypothesis of this study is "There is significant relationship between price fairness and customer anger". The strength of this relation is .519 who is very strong relation and standard error is .039 it means other factor does not highly effects on this relation. The P-value of this relation is .000 who is $.000<.05$. It means there is a significant relationship between price fairness and customer anger. The companies should carefully form pricing policies in order to remove customer anger. The fifth hypothesis of this study is "There is a significant relation between price fairness and satisfaction". The strength of this relation is .523 who is very strong relation and standard error is only .069. So, there is no problem in this relation because the other factor impact is very weak. The P-value of this relation is .000 who is $.000<.05$. So, I conclude that there is a significant relationship between price fairness and satisfaction of the customer. The companies should form a pricing policy carefully because it does create a strong impact on customer satisfaction. The sixth hypothesis for this study is "There is significant relationship between customer anger and customer satisfaction". The strength of this relation is .502 who is very strong relation and standard error is only .053.So, there is no problem in this relation, because the other factor impact is very weak. The P-value of this relation is .000 who is $.000<.05$. So, I conclude that there is a significant relationship between customer anger and satisfaction of the customer. The companies should try to eliminate the anger of customer in order to get customer satisfaction. The seventh hypothesis is "Customer anger mediates the relationship between referent price and customer satisfaction". The direct effect of referent price on satisfaction is non-significant and the mediation of this hypothesis is significant the P-value of this hypothesis is $.000<.05$. So, I conclude that customer anger mediates the relation between referent price and satisfaction of customer. The referent price own does not significant impact on satisfaction. So, it means the customer anger fully mediate the relation. The $8^{\text {th }}$ hypothesis is "Customer anger mediates the relationship between price fairness and customer satisfaction" The direct effect of price fairness on satisfaction is significant and the mediation of this hypothesis is significant the P-value of this hypothesis is $.000<.05$. So, I conclude that customer anger mediates the relation between price 
fairness and satisfaction of customer. The referent price own significant impact on satisfaction. So, it means the customer anger partially mediate the relation. The $9^{\text {th }}$ hypotheses is "Customer anger mediates the relationship between referent deservingness and customer satisfaction" the mediation of this hypothesis is significant the P-value of this hypothesis is $.000<.05$. So, I conclude that customer anger mediates the relation between referent deservingness and satisfaction of customer.

\section{DISCUSSION}

The fast food industry is growing rapidly in these days especially after 2012 (Susilo, 2020). In this situation, they are facing a number of challenges, because fast food is not the primary food of customers. People like it due to new delicious taste; it takes little time for preparation and it charges a fair price (Lastner et al., 2019). But even now, a large number of people don't like fast food, they depend on traditional food, because traditional food has a low price as compared to fast food, and it provides more energy to human body as compared to fast food (Suhud et al., 2020). The traditional market based on traditional food and places it earning a lot of revenue due to the attraction of national and international visitors (Suhud \& Wibowo, 2016). But, the youngster and teenage people do not like it very much (Khokhar \& Khokhar, 2020). Because, traditional food doesn't have more delicious taste and it takes more time for preparation as compared to fast food. Due to this, a large number of big and small food corporations operate in fast food. They are creating fierce competition in the fast-food industry. People have a lot of choices in fast food and they choose those foods that are comparatively low cost and other customers also appraising it (Ahmed, Naseer, Asadullah, \& Khan, 2020). There are a number of items in the fast-food industry and those items will become more popular, whose cost is low (Lastner et al., 2019), and existing customers provides favorable reviews for these items. So, in this situation, fast food industries have two major issues, who they should be solved at their priority. The first is the fair price that they should be charge for a product that should be low as compare to other products in the market and customers also perceiving that this product have a fair price (Susilo, 2020). In our study, we also prove that, referent and fair price is a very important factor in the fast-food industry. The second is the fast-food industry should eliminate negative factors from their business (Min, Joireman, \& Kim, 2019). Due to these factors, customers become angry and they avoid transacting (Riquelme et al., 2019). For this purpose, fast food industry carefully study the psychology of customer regarding their services and list down all factors who creates a negative feeling in customer mind regarding the fast food industry services (Cheshin et al., 2018; Glikson et al., 2019). The customer experience is also becoming an opportunity for companies to change their operation (Watkinson, 2013). The fast-food industry also should keep an eye on existing customer's reviews. When they make their policies regarding their operation especially for pricing, then they should also discuss the reviews of customers. The positive word of mouth of existing customers' is very important for a new customer who involves in purchase decision (Trafialek et al., 2019). This study is very useful in fast food industry for all managerial level and academic literature. The data and their results are very useful for all fast food industry managers. Due to this study, they should be able to formulate effective policies regarding pricing and customer service. The research also has some limitations that we collect data only from 306 respondent and the respondent belonged to Lahore only, when this study will be conducted in any other industry with a different number of respondents, then the result must be different and may be more useful. The independent variable in this study is referent price, fair price and referent deservingness, but the future researcher may take customer service, product quality, perceived customer ethnicity, or any other independent 
variable or change the position of the existing research model (Konuk, 2019). This research is done in a non-contrived natural environment. If a future researcher makes artificial environments for data collection, then the result may be different. In this study, I used the schedule questionnaire technique, but if another technique for data collection will be used, then the result must be altered and will be more useful. The background of this theory is equity theory of Adam Stacy if another marketing theory just like market and exchange, stakeholder equity theory could be applied on this research. So, there are the numbers of limitation and future implication lies on this research, and this research give an open environment for study to future researcher.

\section{COCLUSION}

This research based on consumers of the fast-food industry. In this study, we examine the behavior of consumers regarding fast food industry policies regarding pricing and existing customer's reviews impact on new customers (Trafialek et al., 2019). The background theory of this study is equity theory, who says that if input against any product or service justifies its output as per customers' perspective, then the customer satisfies through it and comes here in the future, otherwise customer moves from there (Konuk, 2019). The fast-food industry should be keep eye on existing customer's reviews and all psychological factors of consumer behavior that become a customer are angry. The price and customer review proves the core factor for satisfying the customers in the fast food industry as per our estimation. The removal of negative elements in fast food industry services is very important for reducing customer anger in order to enhance satisfaction of customer.

\section{REFERENCES}

Ashworth, L., \& McShane, L. (2012). Why do we care what others pay? The effect of other consumers' prices on inferences of seller (dis) respect and perceptions of deservingness violation. Journal of Retailing, 88, 145-155. https://doi.org/10.1016/j.jretai.2011.10.004.

Abeyta, A. A., Routledge, C., \& Sedikides, C. (2017). Material meaning: Narcissists gain existential benefits from extrinsic goals. Social Psychological and Personality Science, 8(2), 219-228.

Atmaja, G. K. K., \& Yasa, N. N. K. (2020). The Role of Customer Satisfaction in Mediating the Influence of Price Fairness and Service Quality on the Loyalty of Low Cost Carriers Customers in Indonesia. International Research Journal of Management, IT and Social Sciences, 7(5), 149-159.

Adam, H., \& Brett, J. M. (2018). Everything in moderation: The social effects of anger depend on its perceived intensity. Journal of Experimental Social Psychology, 76, 12-18.

Ahmed, A., Naseer, R., Asadullah, M., \& Khan, H. (2020). Managing Service Quality, Food Quality, Price Fairness and Customer Retention: A Holistic Perspective.

Arshad, S., Jugo, A., \& Rohin, T. (2017). Valutaeksponering i den norske sjфmatindustrien (Bachelor's thesis, Høgskolen i Oslo og Akershus). 
Ahrholdt, D. C., Gudergan, S. P., \& Ringle, C. M. (2019). Enhancing loyalty: When improving consumer satisfaction and delight matters. Journal of Business Research, 94, 18-27.

Ali, L., Yee, W. F., Imm, N. S., \& Akhtar, M. S. (2018). Price fairness, guest emotions, satisfaction, and behavioral intentions in peer to peer accommodation sector. Journal of Global Business Insights, 3(2), 41-51.

Bolton, L. E., Keh, H. T., \& Alba, J. W. (2010). How do price fairness perceptions differ across culture? Journal of Marketing Research, 47, 564-576. https://doi.org/10.1509/jmkr.47.3.564.

Cronbach, L. J. (1951). Coefficient alpha and the internal structure of tests. psychometrika, 16(3), 297-334.

Chowdhury, S., Meero, A., Rahman, A.A.A., Islam, K. M. A., \& Zayed, N. M., Hasan, K.B.M. R. (2021). An Empirical Study on the Factors Affecting Organic Food Purchasing Behavior in Bangladesh: analyzing a few factors. Academy of Strategic Management Journal, 20(4), 1-12. Retrieved from https://www.abacademies.org/articles/Anempirical-study-on-the-factors-affecting-organic-food-purchasing-behavior-inbangladesh-analyzing-a-few-factors-1939-6104-20-4-815.pdf

Cai, R., \& Chi, C. G. Q. (2018). The impacts of complaint efforts on customer satisfaction and loyalty. The Service Industries Journal, 38(15-16), 1095-1115.

Cerny, B. A., \& Kaiser, H. F. (1977). A study of a measure of sampling adequacy for factoranalytic correlation matrices. Multivariate behavioral research, 12(1), 43-47.

Cheshin, A., Amit, A., \& Van Kleef, G. A. (2018). The interpersonal effects of emotion intensity in customer service: Perceived appropriateness and authenticity of attendants' emotional displays shape customer trust and satisfaction. Organizational Behavior and Human Decision Processes, 144, 97-111.

Darmawan, M. D. (2018). The Effect of Price, Product Quality, Promotion, Social Factor, Brand Image on Purchase Decision Process of Loop Product on Youth Segment (Case Study of Pt Telekomunikasi Selular). In Proceeding of International Seminar \& Conference on Learning Organization.

Dinçer, M. Z., \& Alrawadieh, Z. (2017). Negative word of mouse in the hotel industry: A content analysis of online reviews on luxury hotels in Jordan. Journal of Hospitality Marketing \& Management, 26(8), 785-804.

Dekker, T. (2018). Just Wages, Desert, and Pay-What-You-Want Pricing. Erasmus Journal for Philosophy and Economics, 11(2), 144-162.

Feather, N. T. (2015). Analyzing relative deprivation in relation to deservingness, entitlement and resentment. Social Justice Research, 28(1), 7-26. 
Ferguson, J. L. (2014). Implementing price increases in turbulent economies: Pricing approaches for reducing perceptions of price unfairness. Journal of Business Research, 67(1), 2732-2737.

FAO, (2019). 2050: UN tercio mas de bocas que alimentar. [Organization de las Naciones Unidas para la Alimentacion yla Agricultura. Retrieved from http://www.fao.org/news/story/es/item/35675/icode/

Galton, F., \& British Association. (1885). Section H. Anthropology. Opening address by Francis Galton. Nature, 32(830), 507-510.

Glikson, E., Rees, L., Wirtz, J., Kopelman, S., \& Rafaeli, A. (2019). When and Why a Squeakier Wheel Gets More Grease: The Influence of Cultural Values and Anger Intensity on Customer Compensation. Journal of Service Research, 22(3), 223-240.

Goussinsky, R. (2015). Customer aggression, felt anger and emotional deviance: The moderating role of job autonomy. International Journal of Quality and Service Sciences, 7(1), 50-71.

Hu, L. T., \& Bentler, P. M. (1999). Cutoff criteria for fit indexes in covariance structure analysis: Conventional criteria versus new alternatives. Structural equation modeling: $a$ multidisciplinary journal, 6(1), 1-55.

Hasim, M. A., Manaf, S. A., \& Ali, A. M. (2020). ROLE OF PRICE TOWARDS CUSTOMER SATISFACTION. European Journal of Molecular \& Clinical Medicine, 7(3), 41794190.

Hikmawati, N. K., Suhendra, A. A., \& Yunus, E. D. S. (2018). The Influence of Marketing Mix and Customer Relationship Marketing on Marketing Performance of Digital Creative Industry in West Java. Sebelas Maret Business Review, 2(1).

Ibitomi, T. (2018). Effects of Price Fairness and Physical Environment on Customers Patronage in Fast Food Outlets in Nasarawa State, Nigeria, International journal of research and innovation in social Science, 2(12).

Izquierdo-Yusta, A., Gómez-Cantó, C. M., Pelegrin-Borondo, J., \& Martínez-Ruiz, M. P. (2019). Consumers' behaviour in fast-food restaurants: a food value perspective from Spain. British Food Journal, 121(2), 386-399.

Ismagilova, E., Dwivedi, Y. K., \& Slade, E. (2019). Perceived helpfulness of eWOM: Emotions, fairness and rationality. Journal of Retailing and Consumer Services.

Jothilakshmi, M. (2019). Entrepreneurial Impacts of Informal Fast Food: Consumer Perception on Junk Food Sector in Chidambaram Town. Bodhi International Journal of Research in Humanities, Arts and Science, 3(3). 
Jerger, C., \& Wirtz, J. (2017). Service employee responses to angry customer complaints: The roles of customer status and service climate. Journal of Service Research, 20(4), 362378.

Johnston, R., Jones, K., \& Manley, D. (2018). Confounding and collinearity in regression analysis: a cautionary tale and an alternative procedure, illustrated by studies of British voting behaviour. Quality \& quantity, 52(4), 1957-1976.

Kim, J., Kim, P. B., \& Kim, J. E. (2018). Different or similar choices: The effect of decision framing on variety seeking in travel bundle packages. Journal of Travel Research, 57(1), 99-115.

Kaiser, H. 1974. An index of factor simplicity. Psychometrika, 39, 31-36.

Kokkoris, M. D., Sedikides, C., \& Kühnen, U. (2019). Do consumer choices augment narcissism? The role of self-referent processing. Self and Identity, 18(5), 550-575.

Khokhar, Z., \& Khokhar, R. (2020). Influential Factors on Customer Loyalty of La Moosh (Café), Hyderabad, Pakistan: An Empirical Approach. Journal of Economics, Management and Trade, 15-25.

Konuk, F. A. (2019). The influence of perceived food quality, price fairness, perceived value and satisfaction on customers' revisit and word-of-mouth intentions towards organic food restaurants. Journal of Retailing and Consumer Services, 50, 103-110.

Lastner, M. M., Fennell, P., Folse, J. A., Rice, D. H., \& Porter III, M. (2019). I guess that is fair: How the efforts of other customers influence buyer price fairness perceptions. Psychology \& Marketing, 36(7), 700-715.

Lee, S. H. S., \& Fay, S. (2017). Why offer lower prices to past customers? Inducing favorable social price comparisons to enhance customer retention. Quantitative Marketing and Economics, 15(2), 123-163.

Le, A. N. H., \& Ho, H. X. (2020). The behavioral consequences of regret, anger, and frustration in service settings. Journal of Global Marketing, 33(2), 84-102.

Iyiola, O. O., \& Ibidunni, O. S. (2013). The relationship between complaints, emotion, anger, and subsequent behavior of customers. IOSR Journal of Humanities and Social Sciences, $17(6), 34-41$.

Min, H. K., Joireman, J., \& Kim, H. J. (2019). Understanding why anger predicts intention to complain among high but not low power customers: A test of competing models. Journal of Business Research, 95, 93-102. 
Noeth, A. (2018). Developing an emotional appraisal model using unstructured customer feedback-To better understand how customer's emotions influence their Satisfaction and Likelihood to recommend.

Ogbechi, A. D., Okafor, L. I., \& Orukotan, C. I. (2018). Effect of relationship marketing on customer retention and loyalty in the money deposit bank industry. African Research Review, 12(2), 23-34.

Pearson, K. (1895). VII. Note on regression and inheritance in the case of two parents. Proceedings of the royal society of London, 58(347-352), 240-242.

Pérez Villarreal, H. H. (2020). Analysys of consumer behaviour in food consumption decision processes: evidence found in fast food restaurants in México.

Qalati, S., Yuan, L., Iqbal, S., Hussain, R., \& Ali, S. (2019). Impact of Price on Customer Satisfaction; mediating role of Consumer Buying Behaviour in Telecom Sector. International Journal of Research, 6(4), 150-165.

Rai, B., \& Rawal, R. R. (2019). Consumers' Preference of Fast Food Items in Kathmandu Valley. NCC Journal, 4(1), 17-25.

Renic, M., \& Mandic, M. (2018). Pre-testing of a questionnaire for the purpose of testing the models of fairness and loyalty of clients of companies that apply a customer relationship management strategy. Proceedings of the Faculty of Economics and Business in Zagreb, 16(1), 1-19.

Riquelme, I. P., Román, S., Cuestas, P. J., \& Iacobucci, D. (2019). The Dark Side of Good Reputation and Loyalty in Online Retailing: When Trust Leads to Retaliation through Price Unfairness. Journal of Interactive Marketing, 47, 35-52.

Suhud, U., Allan, M., Wibowo, S. F., Sabrina, E., \& Willson, G. (2020). Measuring customer satisfaction of a café and coffee shop colony at a traditional market. Journal of Foodservice Business Research, 23(1), 78-94.

Souiden, N., Chaouali, W., \& Baccouche, M. (2019). Consumers' attitude and adoption of location-based coupons: The case of the retail fast food sector. Journal of Retailing and Consumer Services, 47, 116-132.

Suhud, U., \& Wibowo, A. (2016). Predicting customers' intention to revisit a vintage-concept restaurant. Journal of Consumer Sciences, 1(2), 56-69.

Susilo, A. (2020). Identifying Factors that Affect Consumer Satisfaction of Parklatz Café in Ponorogo City, East Java, Indonesia: An Application of Exploratory Factor Analysis. Falah: Jurnal Ekonomi Syariah, 5(1). 
Shah, M. A. R., Husnain, M., \& Zubairshah, A. (2018). Factors Affecting Brand Switching Behavior in Telecommunication Industry of Pakistan: A Qualitative Investigation. American Journal of Industrial and Business Management, 8(02), 359372.

Savelli, E., Murmura, F., Liberatore, L., Casolani, N., \& Bravi, L. (2019). Consumer attitude and behaviour towards food quality among the young ones: Empirical evidences from a survey. Total Quality Management \& Business Excellence, 30(1-2), 169-183.

Tavakol, M., \& Dennick, R. (2011). Making sense of Cronbach's alpha. International journal of medical education, 2, 53.

Trafialek, J., Czarniecka-Skubina, E., Kulaitiené, J., \& Vaitkevičienè, N. (2019). Restaurant's Multidimensional Evaluation Concerning Food Quality, Service, and Sustainable Practices: A Cross-National Case Study of Poland and Lithuania. Sustainability, 12(1), $1-21$.

Van Kleef, G. A. (2016). The interpersonal dynamics of emotion. Cambridge University Press.

Watkinson, M. (2013). The ten principles behind great customer experiences. Pearson UK.

Watkinson, M. (2019). The Ten Principles Behind Great Customer Experiences. In Marketing Wisdom (pp. 101-114). Springer, Singapore.

Weber, K., Bradley, G. L., \& Sparks, B. (2017). Stressor effects of negative online reviews on anger and burnout in the restaurant industry. International Journal of Contemporary Hospitality Management, 29(11), 2847-2866.

Xiao, A., Yang, S., \& Iqbal, Q. (2019). Factors affecting purchase intentions in generation Y: An empirical evidence from fast food industry in Malaysia. Administrative Sciences, $9(1)$.

Yang, C. S., \& Lee, M. Y. (2008, August). Parametric data mining and diagnostic rules for digital thermographs in breast cancer. In 2008 30th Annual International Conference of the IEEE Engineering in Medicine and Biology Society (pp. 98-101). IEEE.

Zietsman, M. L., Mostert, P., \& Svensson, G. (2019). Perceived price and service quality as mediators between price fairness and perceived value in business banking relationships: A micro-enterprise perspective. International Journal of Bank Marketing, 37(1), 2-19.

\section{Copyrights}

Copyright for this article is retained by the author(s), with first publication rights granted to the journal. This is an open-access article distributed under the terms and conditions of the Creative Commons Attribution license (http://creativecommons.org/licenses/by/4.0). 